
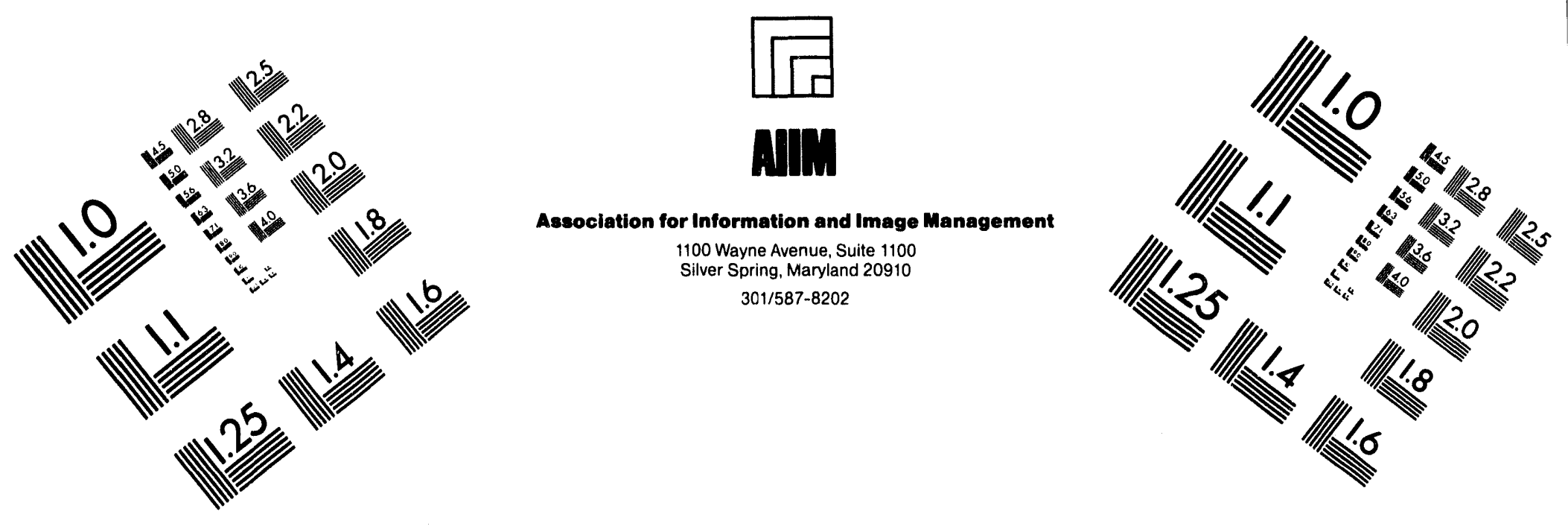

\title{
Centimeter
}

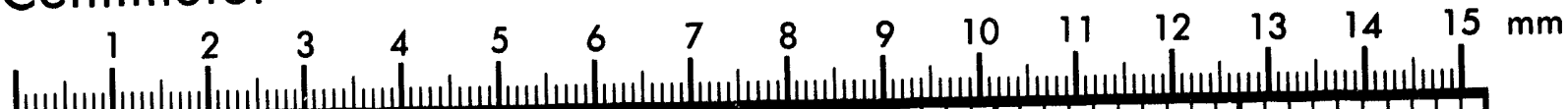

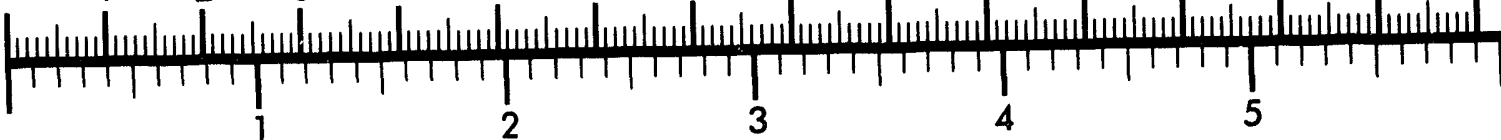
Inches

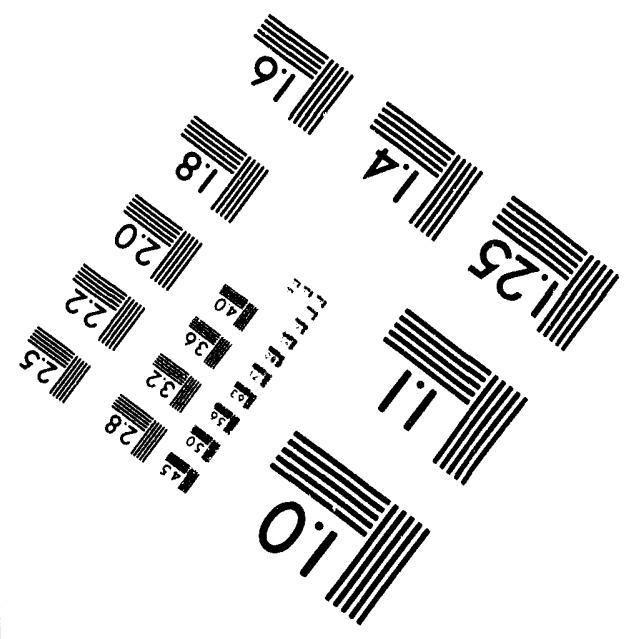

MANUFACTURED TO AIIM STANDARDS BY APPLIED IMAGE, INC.

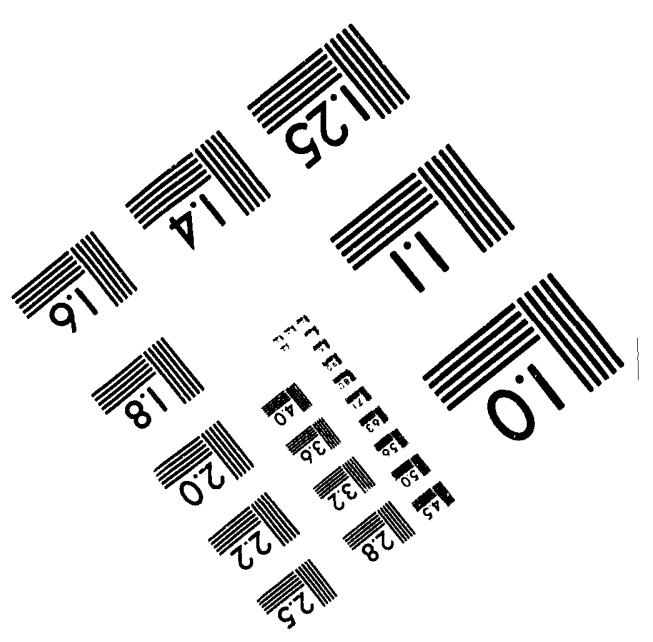



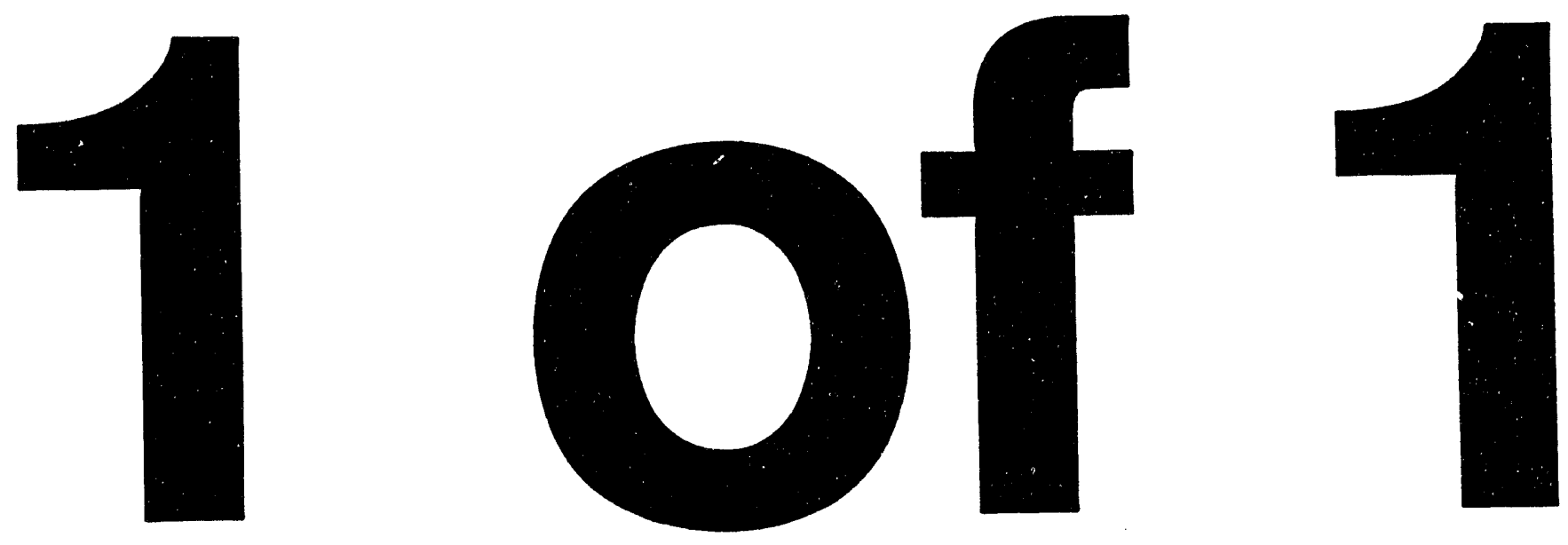
REPORT NO. L-641

(AEC No. 1183-1022)

15 February 1964

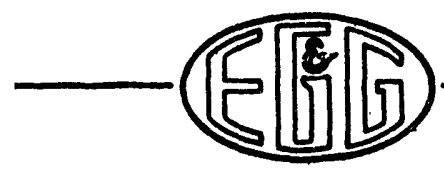

\author{
EG\&G ROVER \\ PROGRESS REPORT \\ FOR \\ 1 - 31 JANUARY
}

Los Alamos Purchase Orders

IC- 2600

IC- $2872-1$

IC- $3001-1$

IC- $3001-2$

IC- 2953

IC- 2959

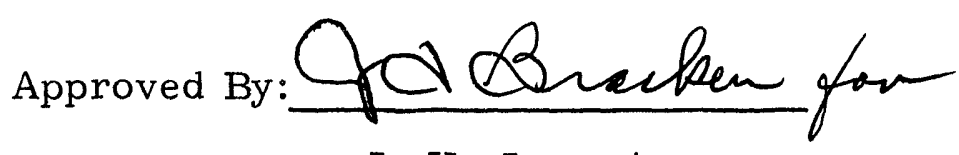

J. H. Jurmain

EDEERTON, GERMESHAUSEN \& GRIER, INC.

Boston, Massachusetts - Las Vogas, Novada

Santa Barbara, California 
TABLE OF CONTENTS

SECTION 1 INTRODUCTION

SECTION 2 TEST CELL A INSTALLATION AND OPERATION $\quad$ 9

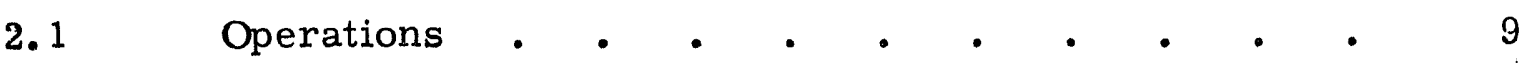

2.2 Installation, Modification and Checkout . . . . 10

2.2.1 Facilities Support • • • • • • . 10

2.2 .2 Controls • . . . . . . • . 12

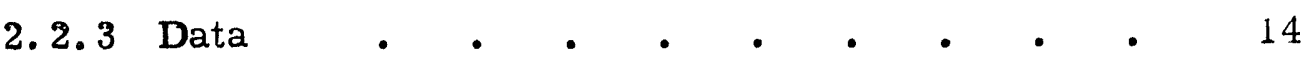

2.2.4 Safety System • • • • • • • . 15

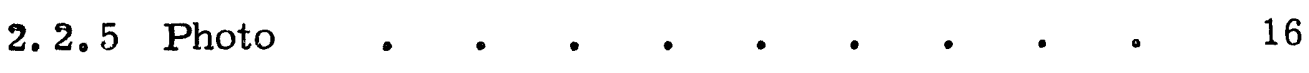

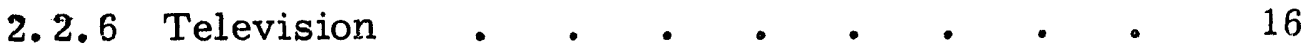

SECTION 3 TEST CELL C INSTALLATION AND OPERATION $\quad$ - 17

3.1 Operations 1 • • • • • • • • • • 17

3.2 Installation, Modification and Checkout . • . $\quad$ - 19

3.2.1 Facilities Support • • • • • • . 19

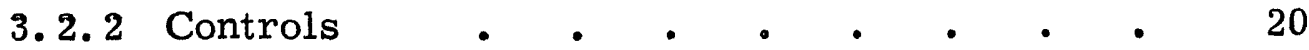

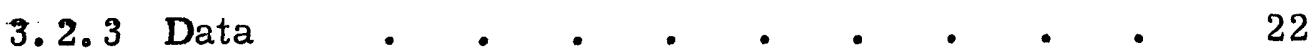

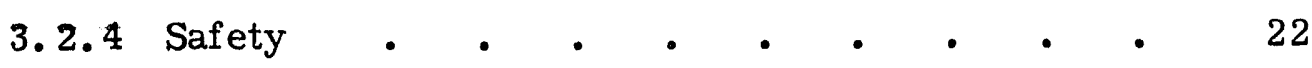

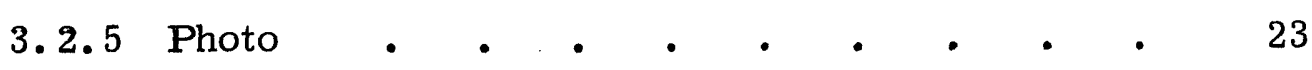

3.2 .6 Television . • • • • • • . 23

SECTION 4 DATA REDUCTION • • • • • • • • • • • 24

SECTION 5 ENGINEERING TEST CELL A $\quad$ • • • • • • • 25

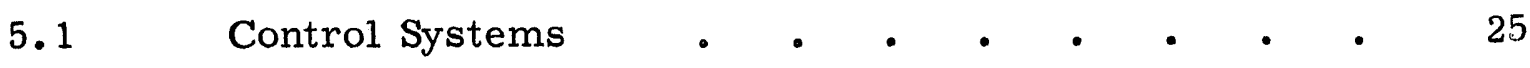

5.1 .1 Shutdown Chassis . . . . • . . 25

5.1.2 Test Cell Isolation Amplifiers . • • . 25

5.1.3 Multiplier Chassis . • . • . . . 25

$5.1 .4 \mathrm{LN}_{2}$ Dewar Control Chassis . . . . 25

5.1.5 Dewar Simulator Chassis . . • . . 25

5.1 .6 Services Console . . . . . . 25

5.1.7 Amplifier Chassis . . . . . . 26

5.2 Neutronics System • • • • • • • • 26 
TABLE OF CONTENTS (Continued)

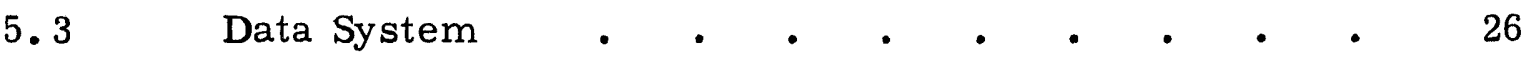

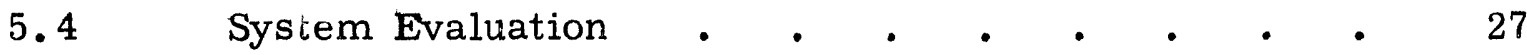

5.5 Test Cell A Operations Support . • • • • 28

5.5.1 Data Systems • • • • • • • • 28

5.5 .2 Neutronics Systems . . • • • • 28

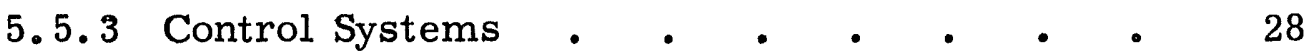

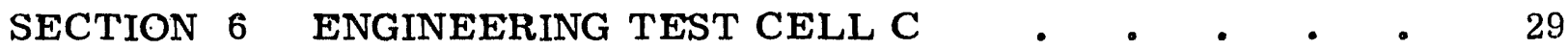

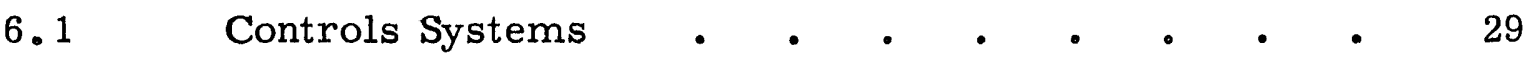

6.2 Neutronics Systems . • • • • • • . 29

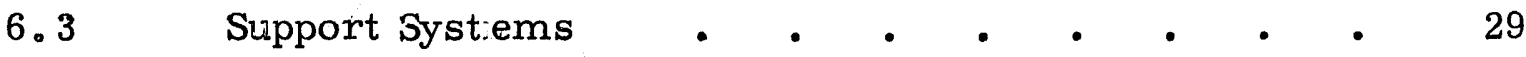

6.4 Data Systems $. \quad . \quad . \quad . \quad . \quad . \quad . \quad . \quad 30$

6.5 System Evaluation $•$ •

6.6 SWET $\quad . \quad . \quad . \quad . \quad . \quad . \quad . \quad . \quad . \quad 32$

6.6.1 Support Systems • • • • • • • 32

6.6.2 Data Systems . • • • • • • 32

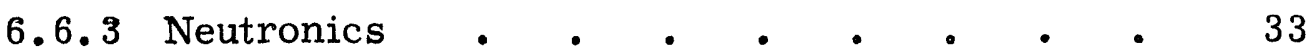

6.7 Test Cell C Operations Support $\quad . \quad$ • $\quad . \quad . \quad 34$

6.7.1 Data Systems • • • • • • • 34

6.7 .2 Neutronics Systems $\quad$ • • • • • • 34

6.7 .3 Control Systems • • • • • • • 34

SECTION 7 ENGINEERING - PHOEBUS $\quad \cdot \quad \cdot \quad \cdot \quad \cdot \quad \cdot \quad \cdot \quad \cdot 35$

SECTION 8 NETWORK ANALYSIS . • • • • • • 36

8.1 Rover Inventory $\quad$ •

APPENDIX A TEST CELL A AREA • • • • • • 37

Channel Engineering and Wiring Records . • 37

Wiring Records • • • • • • • • 38

TEST CELL C AREA

Channel Engineering • • • • • 。 39

Wiring Records

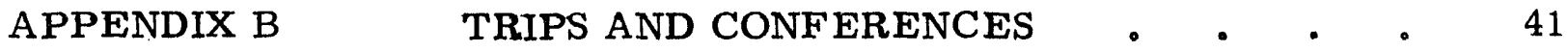


TABLE OF CONTENTS (Continued)

APPENDIX $\mathrm{C}$ APPENDIX D APPENDIX E
REPORTS ISSUED DURING JANUARY • 4.2 OVERTIME REPORT . • . . . . 43 PERSONNEL LEVEL REPORT • • • • 45

LIST OF ILLUSTRATIONS

Figure No.

1.1

1.2

1.3

1.4

1.5

1.6

1.7

1.8
Test Cell A Installation and Operations . . 2

Test Cell C Installation and Operations . . 3

Data Rediction . . . . . . . 4

Engineering - Test Cells A \& C . $\quad$ - 5

Engineering - Phoebus • • • • • 6

Network Analysis • • • • • . 6

Total FY 64 Operating Budget(Excluding Equipment) 7

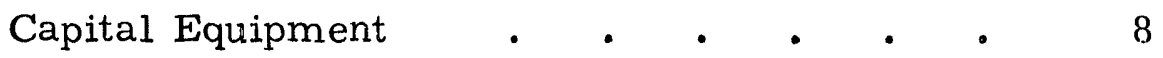




\section{SECTION 1 \\ INTRODUCTION}

This report describes EG\&G activities in support of the Rover Program for the month of January, 1964. Details are discussed in succeeding sections and in the appendices with respect to the various tasks included in our scope of work.

At Test Cell A, the Facility Mapping Test, EP-IV, was successfully completed. Preparation continued for the NRX-A 1 program scheduled for February, 1964.

At Test Cell C, a high flow acoustics test, EP-I, was conducted. This was the last experimental plan to be completed before the Kiwi-B4D cold flow test series, scheduled to begin on 31 January 1964.

Cost curves, except for Test Cell C Operations, still are somewhat below the budget. 


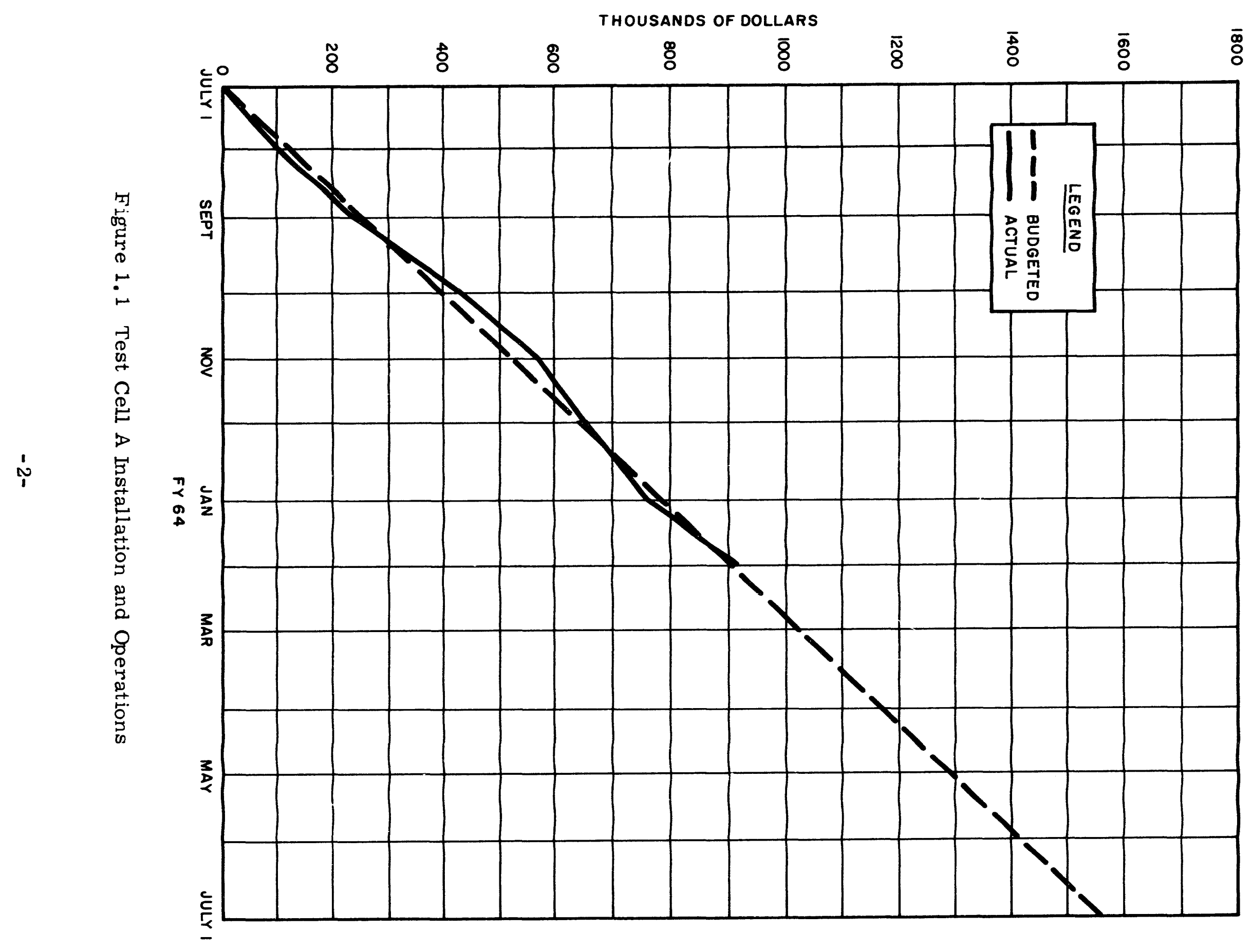




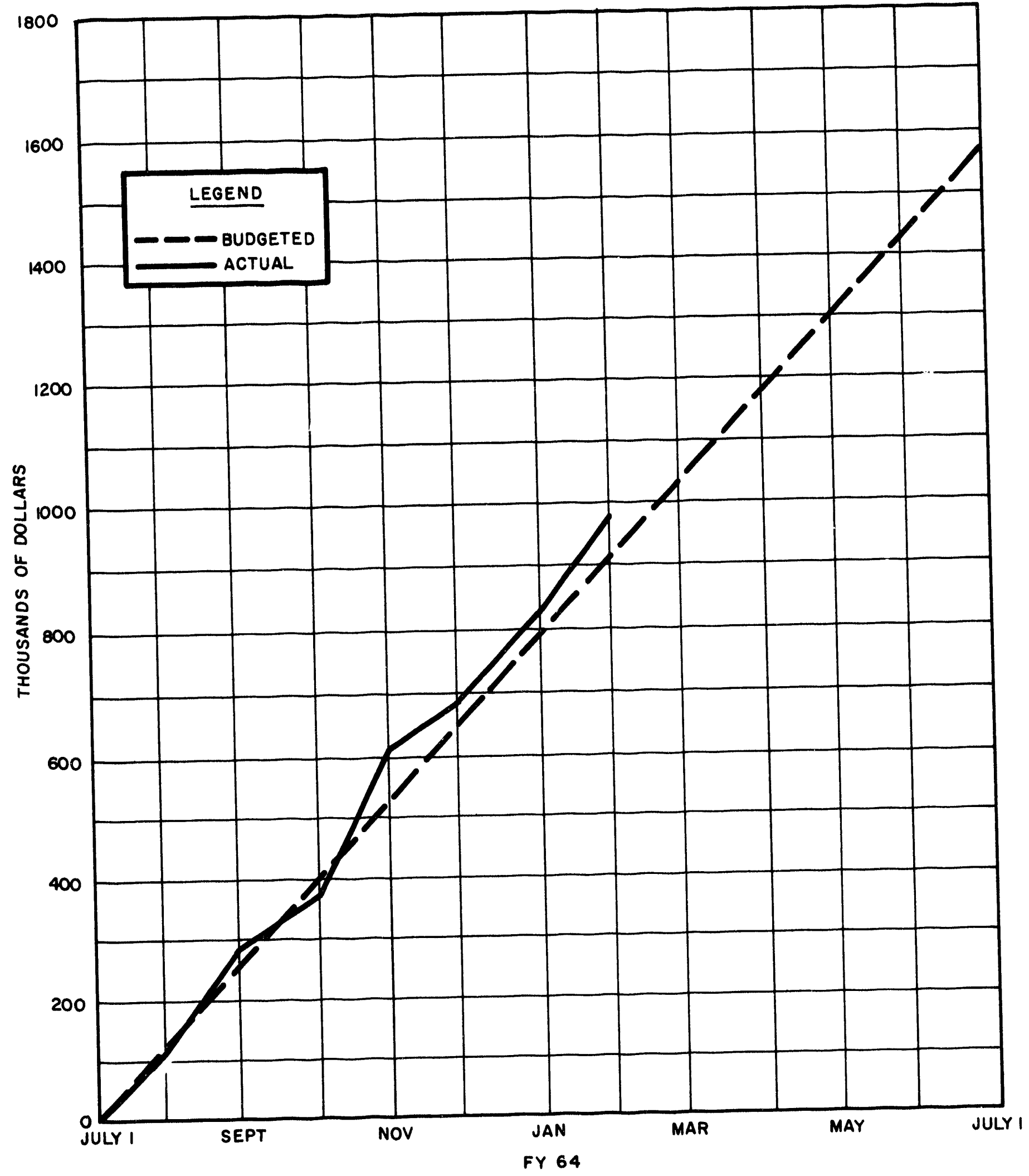

Figure 1.2 Test Cell C Installation and Operations 


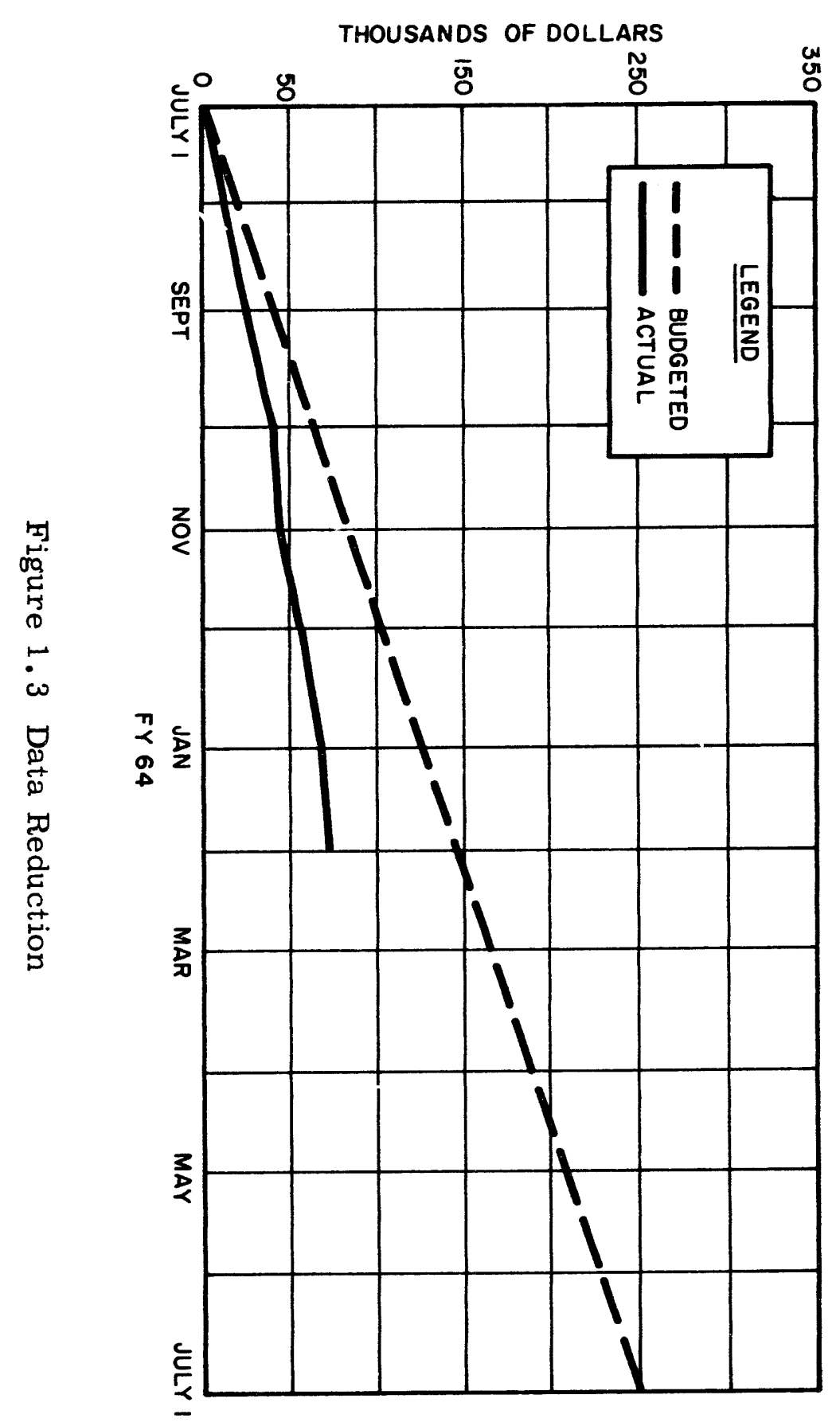




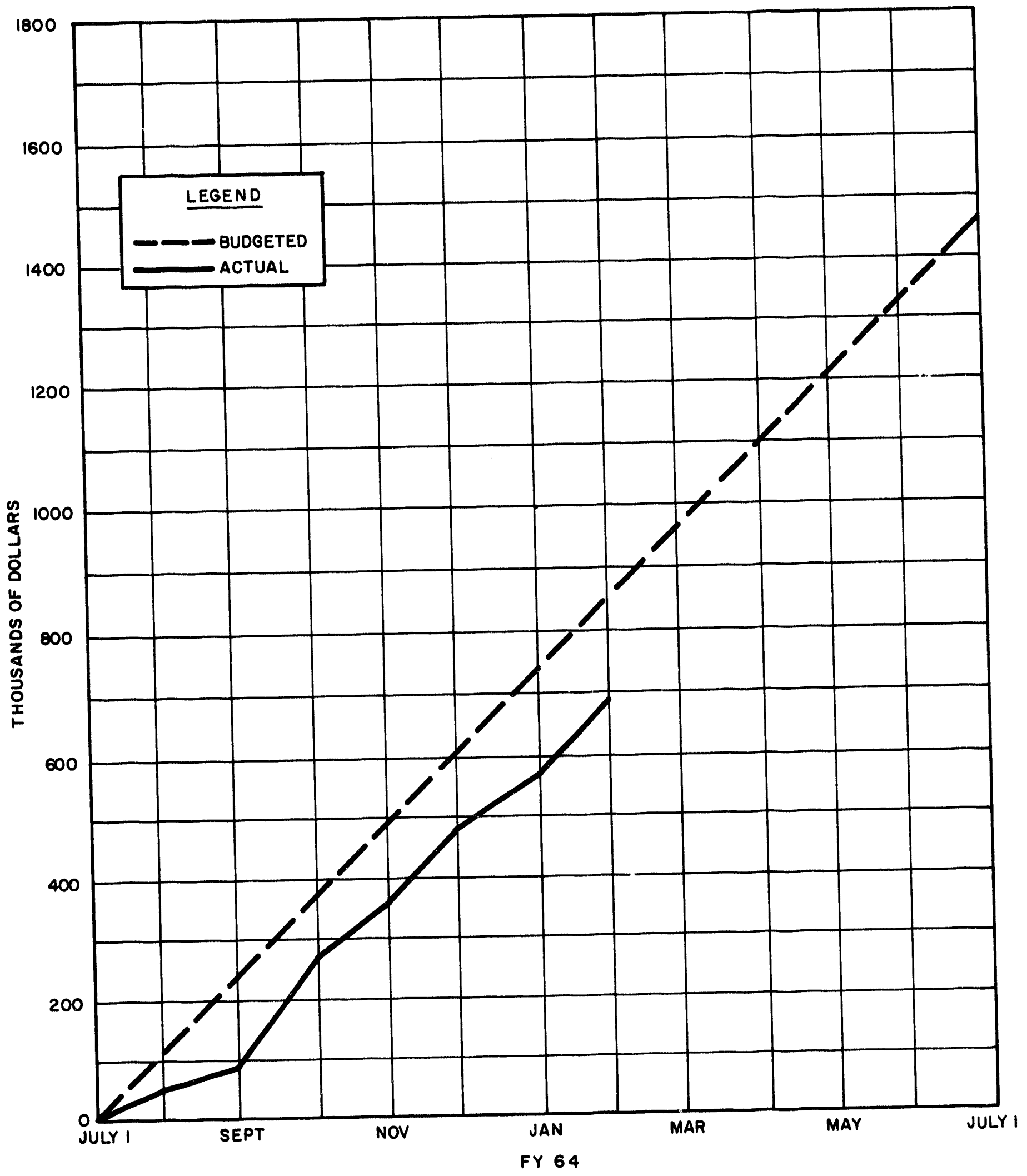

Figure 1.4 Engineering - Test Cells A \& C 


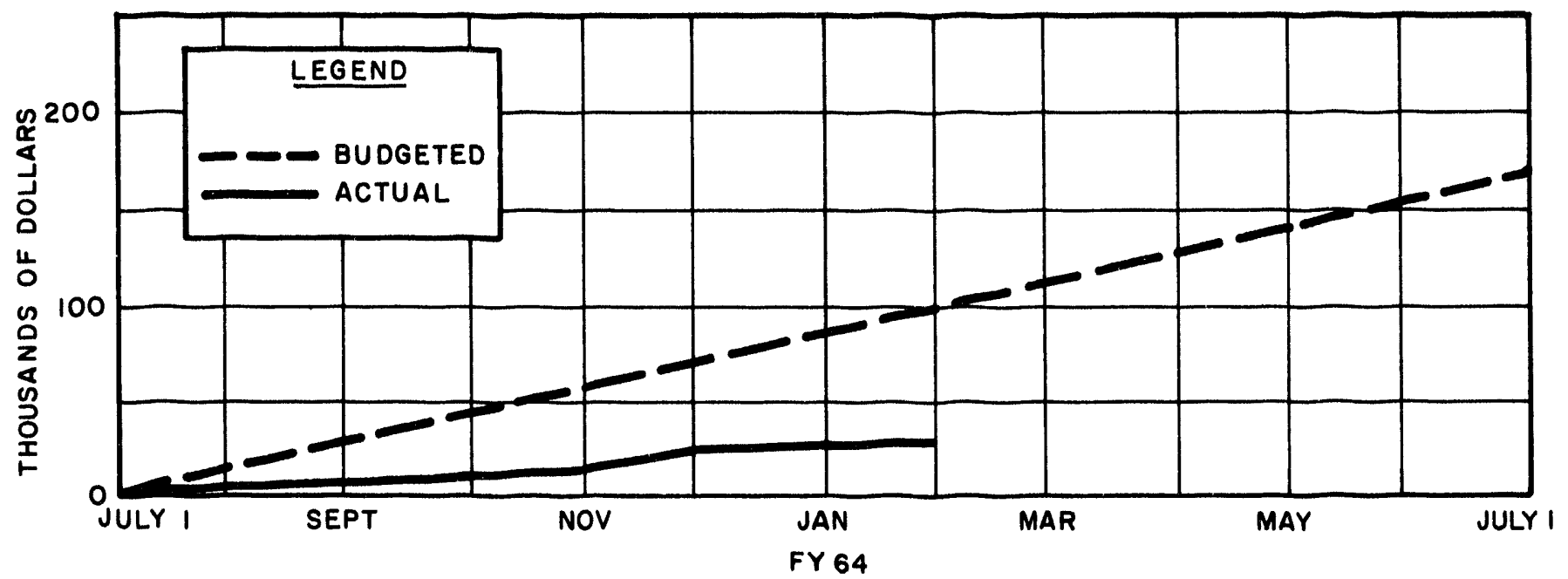

Figure 1.5 Engineering - Phoebus

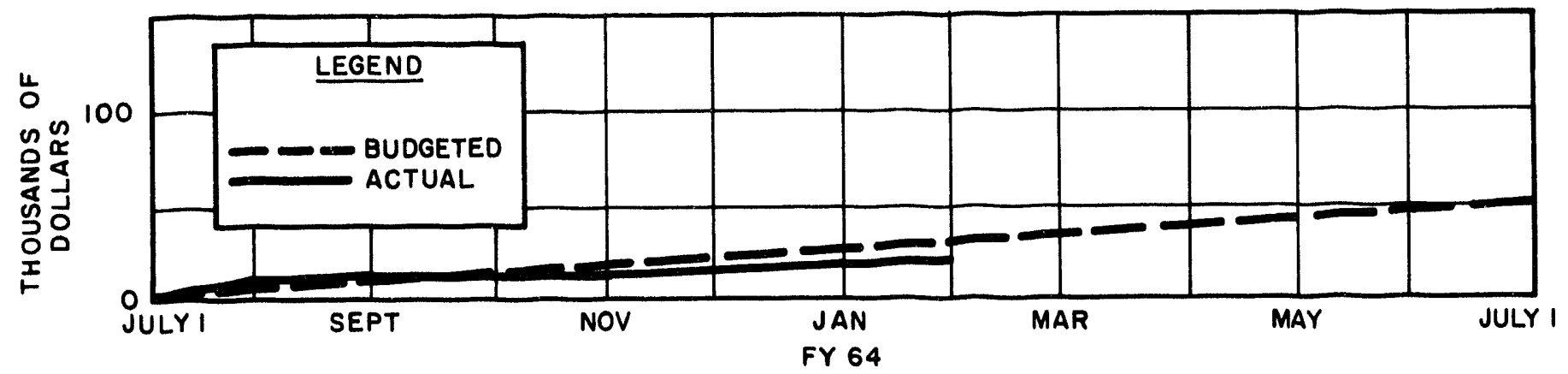

Figure 1.6 Network Analysis 


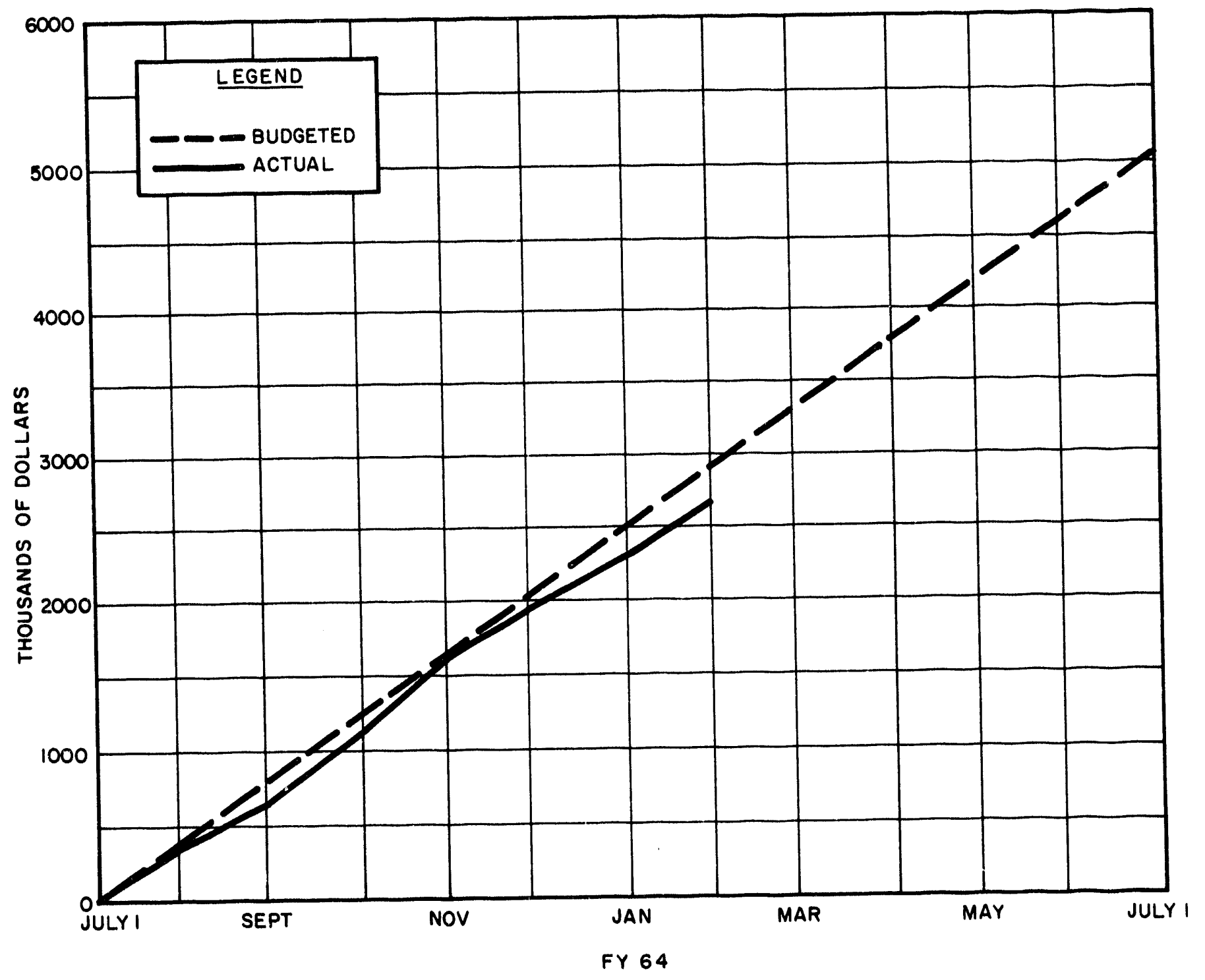

Figure 1.7 Total FY 64 Operating Budget (Excluding Equipment) 


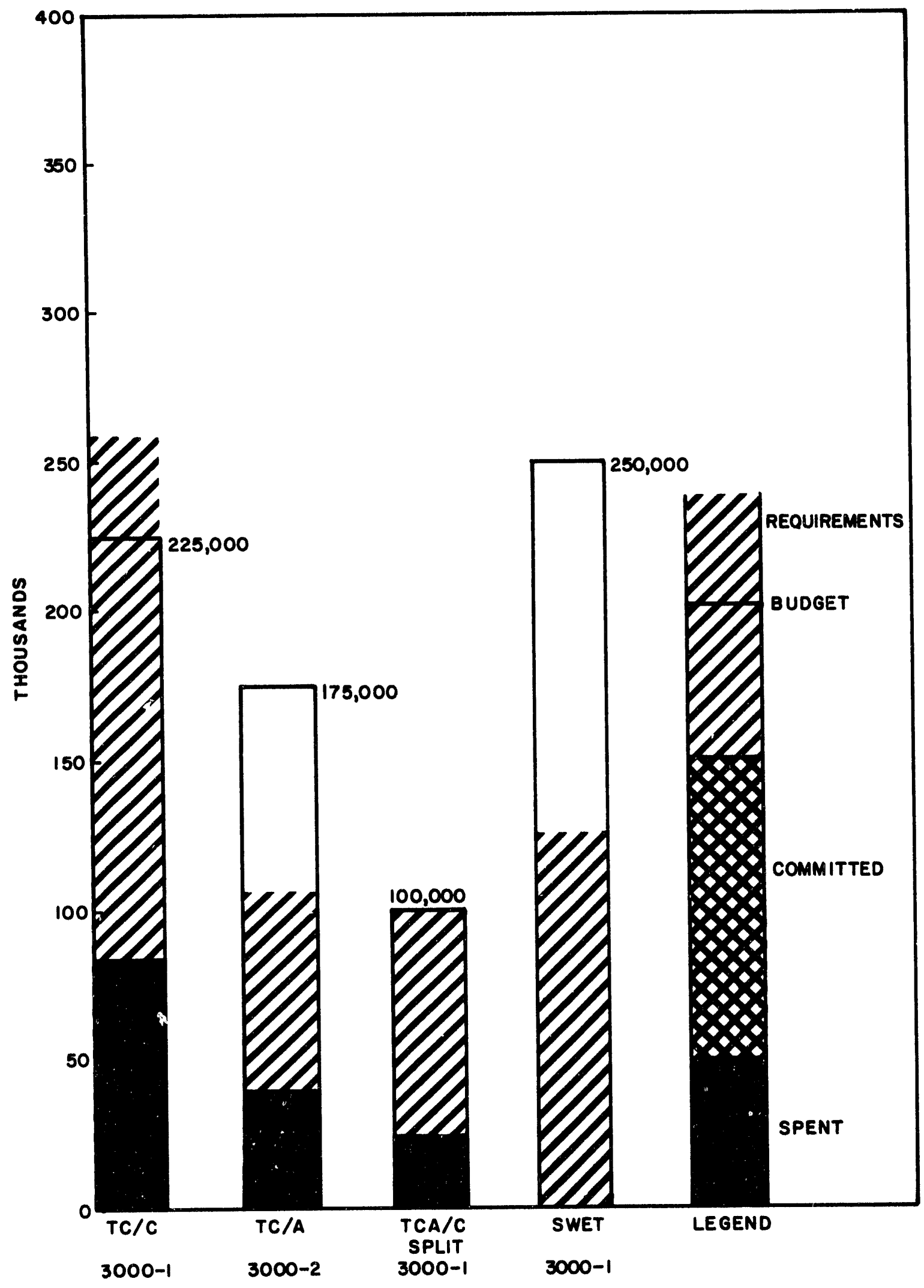

Figure 1.8 Capital Equipment 


\section{SECTION 2}

\section{TEST CELL A INSTALLATION AND OPERATION}

\subsection{OPERATIONS}

Preparations for the forthcoming NRX-A1 tests accounted for most of the work activity at Test Cell A.

The Facility Mapping test series was concluded with Experimental Plan IV on 23 January 1964. Test objectives included (1) frequency response measurements in the temperature control loop and the $\mathrm{LH}_{2}$ flow control loop; (2) investigation of the mixing chamber performance characteristics at limiting conditions relative to NRX-A1 requirements; and (3) a start-up of the system utilizing NRX-A1 flow profile ramp rates.

There were no exceptions to the checklists on 'either R-1 or $\mathbf{R}-0$.

The disposition of discrepancies encountered during the run was as follows:

i1) A one percent offset was noted in channel P. - 200. -A1 (D/ Ppressure Between Mixing Chamber and Orifice). The reason for the offset was not apparent. The problem was remedied by resetting both the low and high ends of the channel.

(2) The Sanborn recorder for channel P.-126. $-\mathrm{AL}\left(\mathrm{LH}_{2}\right.$ Differential Pressure Inlet Venturi) indicated noise up to $80 \mathrm{milli}$ volts in amplitude. A post-run check of this channel failed to detect more than 6 millivolts of noise. The channel is normal at zero, half scale and full scale.

3) Considerable noise was also recorded on the CEC for channels H. -013.-AL and H. -014.-AL. The problem is still being investigated. Discontinuous data on channel $\mathrm{H}_{\bullet}-013$. -AL was traced to a broken shield on the microdot cable which runs from the crystal transducer to the cathode follower. 
(4) The control system 250-volt Offner power supply "crossed-over" during the run. The cause has not yet been isolated. The cross-over unit was checked and reset according to procedure. Operation was normal and remains so. Both power supplies were at 250-volts when checked after EP-IV.

(5) Transducer damage caused a 7 percent offset in channel P. -198. - AL ( $\mathrm{LH}_{2}$ Differential Pressure Between PT-56 and PT-187). Excessive pressure on the low side of this unidirectional transducer caused it to fail.

\subsection{INSTALLATION, MODIFICATION AND CFECKOUT}

\subsubsection{Facilities Support}

The relocation of A1-E128 (FCR Local Control Box) for PCV-123 (Core Purge Valve) has been completed. The box was relocated because the $\mathrm{LN}_{2}$ Dewar piping was blocking the control box door.

Six relays in the relay control box for PCV-39 were found to be faulty and were replaced. Prior to this, PCV-39 would not operate remotely. The valve is now operational in all respects.

Turbine supply valve, PCV-50, was modified by removing the dome, which was not in use, and by relocating the stem and feed back pots. An explosion-proof annin stem pot equipment box was install to standardize this valve with others in the test cell. The dome was originally used to house the valve servo amplifier now located in the local control box.

Local control boxes, A1-E037 and A1EO87 in the FCR, were modified to allow easy access to the amplifier and power supply plug-in boards.

Bank No. 4, GN 2 fill valve (OFV-17), would not operate properly. A check of command channels revealed faulty diodes in the A5-EOO3 relay box for the valve command relays. One diode was open and the other was shorted. Replacing these diodes restored the valve to normal operation. 
All low-level signal conditioners were moved from A1-R076 to A1-R080. A1-R076 could then be removed to allow a walk-way between racks in the RER.

Box A4-B007 has been installed in the Dewar area and will be used as a terminal box to relieve the congestion ir A4E001. Five 18-pair cables are being pulled from the ELR, A1-B040 and terminated in A4-B007. When down-time permits, the change from A4-E001 to A4-B007 will be completed.

Module locks were changed on the voice tape lockouts for the $\mathrm{H}_{2}$ voice annunciator, neutron voice annunciator, and TFC hydraulics. Locks on these modules could all previously be switched with a common key. To avoid accidental switching of the wrong module, the locks were changed so that each module would require separate keys.

The installation and checkout of ACV-10, $\mathrm{LN}_{2}$ Dewar inerting valve, has been completed. A shorted command pot was replaced in A2-R010, panel B, type G module, for ACV-10.

A communications monitor with a desk mike was installed for J-5 operators in the DBC, A2-R008, panel E.

A function generator and oscilloscope were installed in A1-R045, panels B and C. This equipment was used in conjuction with the rods control system checkout setup. Two temporary channels were run from the rods equipment racks A1-R045 and A1-R046 in the RER to the Sanborn patch panel in the DBC. A frequency response test of the rods control system equipment was performed. Support was provided by WANL for the test. 
The binary coding decimal converter, used in conjunction with the photo timing lights north and south of the pad area, was installed in the DBC, A2-R007, panel C. A cable harness was installed for the time code readout chassis 1Jcated in the DBC, A1-R007, panel H. This system is now in operation and has been checked from the CP to all remote readout units. The reason for the system change was the installation of the new Astro-Data time code generator in the CP. The modifications consisted of internal wiring changes required to make the new equipment compatible with existing equipment.

The McIntosh power amplifiers and Public Address system relay panel were moved from A1-R036 to A1-R102.

The intermediate box installation for Pan-Am equipment has been completed. The following systems were isolated and checked out: Public Address system, $\mathrm{H}_{2}$ Siren and Road Warning systems, Neutron Klaxon Alarms system, and all ETL channels. Channel indexes, wiring diagrams and systems schematics were drawn and turned over to Records and Drafting.

Two phone jacks on the Rocketdyne pump for station 40 were replaced. These jacks were torn off when the pump blew up in October 1963. The phone jacks were rewired and checked out.

Eleven 22.5-volt Rod Scram batteries were replaced in A1-R045.

In the ETL, four thermocouples were installed in the gas accumulator and checked for proper operation. Transducers were calibrated and a patch board was set up for a Spider Nozzle test.

\subsubsection{Controls}

The following equipment and control circuit alterations were made in Control Room A:

1) Modular d-c followers and pots were installed in shassis 01D, 02A, 02B, 05F, 06D, 03B and 04C. This included 
the installation of the new $d-c$ components and wiring.

2) The d-c follow-up amplifier chassis 05G,06 $\mathrm{H}$ and $07 \mathrm{G}$ have been modified to be made compatible with the new d-c follow-up system. The changes involved gain circuitry, mode controls and minor design imporvements. The compensation network across amplifier No. 9 was changed in chassis 05G, (Position Simulator for PCV-41) to reduce the noise in that part of the system.

3) The d-c follow-up systems have been operationally checked.

4) Zero suppression unit No. 9 in chassis $20 \mathrm{~A}$ was found to be inoperative. Both the amplifier module and the motor module were replaced.

5) The meter for M-61 was found to be nonlinear from 40 percent to 100 percent of full scale and has been replaced.

6) The 100-volt crossover networks and the two additional 100-volt power supplies were installed and checked out. This included the mounting of new front panels on all the 100-volt power supplies.

7) Rods system chassis 04A was modified to correct a noise problem associated with the P-2 amplifiers.

8) Total flow indication was removed from the local patch panel and wired direct to the CTO console via amplifier module No. 8 in chassis $05 \mathrm{G}$.

9) The EEM console was relocated from the south to the west side of.the Control Room. Internal wiring has been completed except for the multiconductor timer cables.

10) Modifications were made to allow for quick changeover from F-25 to FE-10 flow feedback for PCV-41 at the G-FLO console. 
11) The rack extension program in Control Room $A$ is 90 percent complete.

\subsubsection{Data}

The Data Acquisition System Accuracy test was run with d-c voltage on 15 wide-band channels, 15 high-level, narrow band channels, and 15 low-level, narrow-band channels. Arrangements ior this test were as follows: 15 bridge type signal conditioners were set up as voltage dividers for each system; 5 bridge, 5 strain gauge and 5 thermocouple types were set up for the wide-band system; 5 bridge, 5 strain gauge and 5 thermocouple types were set up for the highlevel, narrow-band system; 5 strain gauge, 5 thermocouples and 5 resistance thermometer types were set-up for the low-level, narrow-band system.

The Data Acquisition System Accuracy test a-c portion, was completed on 14 January 1964. The same wideband, high and low-level channels were used as in the d-c test.

Temporary channels were set up from the Test Cell to the Sanborn patch panel at the CP enabling five channels from the wide-band system and six channels from the narrowband, high-level group to be recorded on Sanborns.

Modifications were made to 42 line-driving amplifiers in the wide-band system. The two 250 microfarad filter capacitors were replaced with 500 microfarad units. The current limiting resistors in the Zener diode limiter circuits were changed from 75-ohm, two-watt to 68-ohm, two-watt values.

One SEL multiplexer was installed in AIR007 and has been tied to the low-level patch panel in the No. 2 position. 
Modifications for 60-cycle noise elimination in the line-driving amplifiers were completed. The result was a reduction of noise from a $20 \mathrm{mv}$. to a $3-5 \mathrm{mv}$. amplitude.

All input filter capacitors in the high-level multiplexers were reinstalled and completely checked out. Consequently, several abnormal bits that had been noted before the reinstallation of the capacitors were restored to normal.

The Philbrick amplifier power supplies were moved from A1-R083 to A1-R081. Heat generated by these supplies, which were mounted directly below the Philbrick manifolds, was responsible for frequent failure of the amplifiers in the manifolds.

A complete investigation was made of noise in the tape recording system. It was determined that the majority of the noise is a characteristic of the playback amplifiers and could be avoided by increasing the record head current to 3 milliamps and using a $6 \mathrm{kc}$ low pass filter on the EMR discriminator for playback purposes.

A tunable discriminator was removed from the tape center and installed in the "Quick-Look" facility for use until new filters are received for the existing discriminators.

\section{2.4 Safety System}

All alarm and indication channels were checked on a weekly basis for proper operation.

The changeover of the Hydrogen Alarm Siren, Road Warning Lights, and Hydrogen Voice Tape for Pan-Am isolation has been completed.

The filaments were replaced in both $\mathrm{K}-14$ (Penthouse $\mathrm{J} \&$ W Hydrogen Analyzer) and K-5 (FCR J \& W Hydrogen 
Analyzer). A power transformer was also replaced in K- 14 .

\subsubsection{Photo}

Per NRX-A1 run requirements from WANL, the camera complement will include six $35 \mathrm{~mm}$ Mitchells loaded with Eastman color negative film, four $16 \mathrm{~mm}$ Mitchells loaded with Kodachrome II, and a $16 \mathrm{~mm}$ Milliken (nozzle camera) with Double-X negative film. The camera lenses and mounts have been assembled and are being mounted.

An investigation of the lighting system for the NRX-A1 nozzle photo set-up was undertaken. The present plan incorporates a GE Par 38 spotlight which has been known to explode under shock and to become very unreliable after 15 minutes of continuous operation. Color-Tran., the manufacturer, was consulted and verified these conclusions. An alternate system incorporating quartz-iodine bulbs is now under consideration.

Kinescope coverage was provided for the Facility Mapping test, ET-1V, and the Kine Film has been sent to WTOD for processing. Sanborn charts were microfilmed and Kalfax copies made for the same run.

\subsubsection{Television}

The TV cameras were moved to Test Cell $\mathrm{C}$ and properly located per EP-IV requirements.

Connectors were mounted on 400 feet of G. E. camera cable which was installed for the southwest camera location. 


\section{SECTION 3}

TEST CELL C INSTALLATION AND OPERATION

\subsection{OPERATIONS}

Experimental Plan I, High Flow Acoustics test, was conducted at Test Cell $\mathrm{C}$ on 9 January 1964. The objectives of the test were to measure the acoustic sound levels produced by burning hydrogen at maximum obtainable flow rates and to isolate the effect of burning on the acoustic field by flowing unburned hydrogen, or helium, also at maximum flow rates. An additional aim was to obtain radiant heat flux measurements in the test cart area.

Instrumentation requirements peculiar to this EP were as follows:

1) Command and indication channels were provided for two nozzle shroud purge valves operating in parallel as QEV-902.

2) Five gas bottle temperature channels were used to record the chilling effect produced within the bottles during high rate gas flows. The channels were:

$$
\begin{aligned}
& \text { T-156A-CQ (Helium Bottle, B Temp.) } \\
& \text { T-157A-CQ (Hydrogen Bott1e, G. Temp.) } \\
& \text { T-533A-CQ (Hydrogen Bottle, E. Temp.) } \\
& \text { T-534A-CQ (Hydrogen Bottle, F Temp.) } \\
& \text { T-159A-CQ (Nitrogen Bottle, L Temp.) }
\end{aligned}
$$

3) The test cart instrumentation consisted of the following data channels:

D. -820. - WA Displacement, Vert Press Ves/Core Supp. Plate R-0

D. -821. - WA Displacement, Vert Cor Sup Pli/030-C2 Cluster Pli

H. -905.-CA Accel of Press Ves X-Direction H. -906. -CA Accel of Press Ves Y-Direction H. -907.-CA Accel of Press Ves Z-Direction P. -190. - WA Propel Pressure, Core Exit T-60 P. -191. - WA Propel Pressure, Core Exit T-300 P.-916.-CA Static Pressure, Nozzle Exit Plane 
T. 190. - WA Propel Temp. Core Exit Plenum T-0 5 Inch Insertion

T. -191. -WA Propel Temp. Core Exit Plenum T-120

4) Temperature-sensitive pain was used to obtain fiftyfive temperature measurements at various points in the test cart area.

5) Calorimetric measurements were made at distances out to 1,000 feet from the test cell face.

6) Instrumentation for measuring and recording the acoustic levels during the run were primarily the responsibility of Douglas Aircraft Company. EG\&G personnel assisted in the wiring, installation and calibration of the acoustical channels, as well as providing general support requested by the representatives from Douglas.

The necessary adjustmeits and repairs were made to correct discrepancies encountered during $R-1$ in channels P.-103.-CG, M. -104-CE, M. - 106 and in the gas bottle temperature channels (see No. 2 on previous page).

There were no pre-run discrepancies or exceptions to the check-list on $\mathrm{R}-0$.

The following instrumentation difficulties occurred during the run:

1) Channels P. - 190. - WA (Propellant Pressure, Core Exit T-60) and P. -916. - WA(Static Pressure, Nozzle Exit Plane) failed during the initial gas flow. Inspection of the vibration channels showed accelerations of greater than $100 \mathrm{~g}$ 's peak-to-peak. A re-entry team replaced the transducers and attempted to shock-mount them. This effort was unsuccessful and these channels failed again.

2) Channels P. -191.-WA(Propellant Pressure, Core Exit T-300), H. -905.-CA, H. -906.-CA and H. -907.-CA (Accelerations of the Pressure Vessel in the $X, Y$ and $Z$ Directions) failed and remained inoperative for the remainder of 
the run. Post-run inspection revealed open transducers in each of the channels. The failires were attributed to excessive vibration.

3) Noise indications greater than full scale were noted during the latter part of the run in channel M.-106.-CE(Wind Velocity at Douglas Tower, $20 \mathrm{ft}$, Level). Ine source of trouble was traced to the REECo translator and REECo has been notified accordingly.

4) The auto-ignition of unburned hydrogen occurred during one phase of the run causing minor damage to buildings and equipment in the Test Cell area. Damage to EG\&G instrumentation was confined to the tearing loose of a $\mathrm{J} \& \mathrm{~W}$ hydrogen analyzer from its mountings on the south wall of the Motor Drive building.

\subsection{INSTALLATION, MODIFICATION AND CHECKOUT}

\subsubsection{Facilities Support}

The NFS- 2 brake-pin relay control and indication chassis was modified to provide a 40 volt latch-in voltage and 28 volts for the normal hold-in voltage. The equipment has been operationally checked.

The closed limit positioner cut-outs on JBV-3, 4, 9 and 10 were modified for use as safety backups for the closing torque. The valves will now cut out on torque. If the torque by-pass is used, the limit positioners will cut out at preset values to prevent damage to the valve seats.

A new transducer has been installed for P-248 (JBV22 Upstream Pressure).

Transducers P-908, 909 and 910 were removed and returned to the calibration lab. These transducers were used in 
the acoustic channels for FE-23.

The loss-of-vacuum cans No. 25 and No. 26 were rewired after LASL, J-5, reinstalled them on the $\mathrm{LH}_{2}$ line.

New delta-P transducers were installed on FE-23(P-210) and FE-6 (P-211).

PCV-89, FE-7, P-250 and PP- 89 were removed from the gaseous system for the High Flow Acoustics test. These units were reinstalled and operationally checked after the run.

Thermocouples were mounted on gas bottles B, D, E, F, $G$ and $L$ to record temperature data during EP-I.

All Public Address system equipment has been moved to $\mathrm{C} 1-\mathrm{R} 039$ in the FSC.

A local-remote transfer switch and a local start-stop push button station were installed for the $\mathrm{H}_{2} \mathrm{O}$ pump in the Treated Water system. The " $\mathrm{T}$ " system has been completely checked from the FSC and the CP.

Twenty-six aluminum plates, painted with heat-sensitive paint, were mounted in the test cart area for EP-1.

Eleven permarent, new calorimeters were installed at various positions up to 1,000 feet from the test cell face. Calorimeters have also been mounted around the " $W$ " cart for the Kiwi-B4D Cold Flow test, EP-I.

An OEV relay box was installed in the ELR for the "W" cart valves and Privy blower to provide a bi-polar momentary commands capability at the CP. A holding circuit was also required at the test cell to complete the installation.

\subsubsection{Controls}

The following equipment changes were made in Control Room C:

1) Control Room Sanborns Z2-R023 and Z2-R024 were 
modified to provide a 1 -second marker pulse for time code reference.

2) Installation, modification and checkout of centralized switching for the 28-volt filament and plate voltages (chassis 12G) has been completed. Cabling and modification of the filament plugs on twenty-seven chassis was required to provide interlock circuitry for the system.

3) Chassis 09G was modified to provide a true indication of ACV-16 operate/simulate switching at all times. Chassis 10A was modified to change the RPM controller from three amplifiers to one.

4) The conversion of the a-c servo follow-ups to d-c was completed for the following: PCV-87, 89, ACV-2 (Pos. and $\mathrm{N}_{\mathrm{s}}$ ) and the turbine Speed and Flow. This changeover is now 50 percent complete. The Rods, Temperature, PCV-63 and Electric Drive systems conversions are being scheduled as time permits.

5) A new chassis, 22K (Power Distribution), was installed and checked out. This required the modification of chassis $22 \mathrm{~L}$ to supply \pm 30 volts to chassis $22 \mathrm{~K}$ for distribution to the $d-c$ follow-ups.

6) Chassis $05 \mathrm{~B}, 15 \mathrm{~B}$ and $15 \mathrm{C}$ were modified to provide an automatic start-up for the power control system.

7) Changes were made to chassis $16 \mathrm{D}, 04 \mathrm{~B}, 05 \mathrm{~B}$ and $15 \mathrm{~B}$ to provide an automatic scram reset capability at the CTO console. The modification included the addition of a relay to the Rods command in both operate and simulate positions.

8) All Control Room racks were raised 1/4 inch above the floor level and 1/4 inch'_micarta strips placed underneath, isolating the racks from the Control Point ground. All 
chassis have been checked for proper grounding.

9) The stepping ladder switch at the CTO console has been modified to permit the Gas Controller changes required for EP-1 of the Kiwi-B4D/CF tests.

\subsubsection{Data}

The discriminator rack in the "Quick-Look" station was modified to accommodate five discriminators.

An EMR switchable discriminator was installed in Z3-R165 at the CP.

An auxiliary patch panel was installed for the wave analyzer in the "Quick-Look" station.

The time code reader was moved from Z3-R146 to Z3-R141C and the time code generator was moved from Z3R169 to Z3-R141D, to gain rack positions for additonal FR-600 tape recorders.

In preparation for the Kiwi-B4D/CF test, EP-I, 35 data channels were stimulus checked and the results recorded on a Sanborn.

\subsubsection{Safety}

The Eberline safety monitor previously used at Test Cell A was reconditioned for use at the MAD building.

A red and amber flashing light circuit was provided for the Road Warning Lights system. LASL, J-6, installed a 6 -volt $d-c$ backup battery and flashing red light for the a-c failure alarm on the Road Warning board.

Changes to the $\mathrm{H}_{2}$ Alarm, Neutronics Alarm and Road Warning systems required for the Pan-Am isolation have been completed and doc amented.

Modification of the 8-point $\mathrm{H}_{2}$ analyzer has been completed. Voltages for the sample-select valves were changes from a-c to 28 volts $d-c$. 
Oxygen analyzers in the Flow Control Room (4-point), Propellant Pump Building and Cryogenics Evaluation Laboratory were subjected to a response test. Response times varied from 15 to 103 seconds.

\subsubsection{Photo}

Eight cameras were utilized in filming EP-1, High Flow Acoustics test. Film from the run has been processed and found acceptable.

Special tests were conducted using an Owens-Corning 7-59 U.V. filter and black and white film to establish correct exposure levels for the run.

The new $35 \mathrm{~mm}$ Mitchell cameras were modified by removal of the buckle switch and connector. They are now compatible with the present camera system.

The LASL photo system installation in the bunkers was completed, checked out and run for the Kiwi-B4D/CF, EP-I.

The bunker complements included two $16 \mathrm{~mm}$ Mitchell cameras with Kodachrome film. In addition, one Milliken and one Mitchell cameras were run as system checks for future runs.

Special control boxes were assembled for the DBM5 Milliken Camera, enabling the use of the 1,200-ft magazine with the start/stop capability.

\subsubsection{Television}

Television cameras were placed at locations specified by LASL for the High Flow Acoustics test and EP-I of the Kiwi-B4D Cold Flow tests at Test Cell C. 
SECTION 4

\section{DATA REDUCTION}

There has been no pertinent activity to report. 


\section{SECTION 5}

\section{ENGINEERING TEST CELL A}

\subsection{CONTROL SYSTEMS}

The status of the new schassis for CPA is as follows:

5.1.1 Shutdown Chassis:

Fabrication was completed and a checkout and operation phase has begun in the Las Vegas laboratory.

\subsubsection{Test Cell Isolation Amplifiers}

WANL authorization increased the number required from 20 to 40 . Design and drafting are almost complete.

\subsubsection{Multiplier Chassis}

WANL authorization was received to provide another multiplier chassis. The design is completed. 5.1.4 $\mathrm{LN}_{2}$ Dewar Control Chassis

Chassis completed and delivered to NRDS. No installation and checkout schedule has been set.

\subsubsection{Dewar Simulator Chassis}

Authorization was received to replace the existing Dewar simulator with a new unit containing two simulators. Design is 90 percent complete and drafting started. An investigation has been started to determine the feasability of using Quadratrons in the divider circuit to reduce multiplier and divider cost.

\subsubsection{Services Console}

Front panel drawings associated with rebuilding the Services console were submitted for approval. Several changes were made and a new chassis added. Approval is now expected 2/3/64. All but two chassis will require new front panels and reworked internal circuitry. Two new chassis will be required. 


\subsubsection{Amplifier Chassis}

Authorization for an additional chassis to contain 15 solid state amplifiers was received. The chassis will function as a balanced to single ended converter chassis operating at a 10 volt level. This installation will free $30, \mathrm{~K}-2 \mathrm{X} / \mathrm{K}-2 \mathrm{P}$ pairs for use in the control and simulator equipment operating at a 100 volt level. Two amplifier pairs are required per converter when using the tube amplifiers. One solid state amplifier is required for the same operation.

\subsection{NEUTRONICS SYSTEM}

A detailed work statement, including some 20 tasks, was received from WANL. Work has started on several of these engineering tasks: testing and madification of the e-fold timer, continuation on the design of a four channel automatic auctioneer, and implementing a one channel fission counter calibration system.

\subsection{DATA SYSTEM}

The two $100 \mathrm{KC}$ reference oscillators have been received. They will be installed in the wideband data system when the distribution panels are completed. Fabrication of the distribution panels are now due to be completed by February 7. System installation should be complete by February 14. The oscillators will be used for tape and recorder skew compensation at WANL's Pittsburgh data reduction center.

Requests for Quotation for the ETL analog recorders have been sent to five recorder manufacturers with a bid deadline set at 10 February 1964. The design of the low level sampler chassis has been completed and a 2 March 1964 delivery requested.

A minor logic redesign was required on the new Time Code Reader. After eliminating a series of bad PC cards, the 
reader was checked out and found to work properly, The second unit wiring was completed and the Reader was checked out. Eleven ADC boards were sent back to the factory for repair. At the present time a new modification to the input of the Reader is being designed. The modification will eliminate possible damage to the Schmitt Triggers should the EMR Discriminators put out an excessively high voltage ( $>50 \mathrm{VDC}$ ). A preliminary manual has been released. The two readers will be shipped to NRDS during the first week of February.

An evaluation was performed on the Time Code Annunciator to investigate passible modifications to improve the audio output of the unit. Excessive wow and flutter present the major problems. It is apparent that the drive mechanism could stand improvement. The present system utilizes a low torque, $1.800 \mathrm{rpm}$ motor and a series of pulleys for speed reduction. Since the unit was only available for two days, only minor changes could be made--addition of a fly wheel and replacement of worn bearings. A slight improvement was realized. It appears that mechanical (and some electrical) redesign would be required to completely solve the problems.

\subsection{SYSTEM EVALUATION}

As previously reported, the accuracy tests requested by WANL were performed during the first two weeks of the month. The detailed procedure and completed data sheets have been transmitted to WANL.

Later discussions with WANL resulted in a second evaluation test requirement. The additional requirements initiated a new series of end-to-end tests to determine data system noise, drift, and linearity characteristics. These tests required a new procedure since existing documents. 
proved inadequate to meet the testing criteria proposed by WANL. This additional testing was completed on the 30th of January.

\subsection{TEST CELL A OPERATIONS SUPPORT}

\subsubsection{Data Systems}

Since the three modified S. E. L. commutators still appeared to contain excessive noise Dave Yoder, SEL, visited Las Vegas in an effort to derive a solution. Several small internal wiring errors were discovered, but the major noise sources were found to be extraneous grounds. The multiplexers were sent to the Test Site for installation and checkout in a field environment.

\subsubsection{Neutronics Systems}

Two evaluation tasks, as requested by WANL, have been started. This support includes; bandwidth and phase shift measurements on the entire neutronics control system, and drift tests: on the XAM- 29 logarithmic amplifiers.

\subsubsection{Control Systems}

The new DC follow-ups were installed and checked out as were the automatic reset chassis and split flow systems.

A noise problem has arisen on the multipliers and is being corrected. Indications are that more problems (noise) may recur.

On site checkout has begun on the Test Signal Generator. The wiring to the various systems in the control room is not complete. The output indicator does not appear to operate properly. An effort is being made to define the problem and correct it. 


\section{SECTION 6}

\section{ENGINEERING TEST CELL C}

\section{1 CONTROLS SYSTEMS}

A cost estimate was submitted to LASL along with a suggestion that the existing control room equipment used with the electric drive be considered for installation in the fill station if not required in the control room. This would save on capital equipment cost but does not permit control of the electric drive from the control point except under rather restricted circumstances.

Design was completed and fabrication started for equipment required to expand the data panel by 25 additional isolation amplifiers. (The order included an additional 16 amplifiers for a similar expansion in Control Room A.)

\section{2 NEUTRONICS SYSTEMS}

Specifications have been completed for the Control Room Digital Volt Meters. Vendor literature is being screened for qualified (acceptable) meters.

\section{3 SUPPORT SYSTEMS}

Due to the lack of available long lines running from Test Cell $\mathbf{C}$ to the control point, EG\&G has been asked to consider the possibility of sharing the T. V. System control lines. General specifications are that two cameras may be controlled at any one time and the switching of controls from camera to camera must be accomplished rapidly. Two designs are being considered at the present time, and costs vs. pairs saved estimates being derived.

The mechanical portion of the Photo Vernier Time Readout is complete with the exception of adding a pick-" $\delta$ ff device. The electrical portion of the clock will require some additional design. 
The KinTel Infrared - Television site demonstration. has been delayed until the needed vidicon can be obtained from RCA. Production of the special IR vidicon has been temporarily stopped. GDA has prepared a quote, but it has not yet been received by our purchasing department.

\subsection{DATA SYSTEMS}

The Sanborn Recorder Test Panel design is complete and ready for fabrication. Investigation into available relays for switching signals of low amplitude is in progress. Stringent requirements for low contact resistance necessitate the use of telephone type relays with bifurcated, gold alloy contacts. Delivery time for this type of relay is approximately eight weeks.

The wiring diagram for the test panel is complete. All parts are available from stock except a seventeen position, two wafer, rotary switch which has been ordered.

The Sanborn recorders are to be shipped from the manufacturer on February 19, 1964.

A system block diagra' $\mathrm{n}$ for the 36 Channel Expandable Carrier System has been completed. Requests for quotations have been released concerning the necessary low-pass and bandpass filters. The quotes should be returned to EG\&G by February 6, 1964. Circuits have been designed for the following units:

1. Frequency divider

2. Isolation amplifier

3. AGC control board

4. Calibration voltage modulator

5. Demodulator

6. Demodulator switching voltage phase lock

The circuit designs will be finalized and bread boarded as time allows; Items 4 \& 5 have been built and checked. A module wiring diagram is approximately 50 percent complete. A module packaging scheme has been proposed and will probably be used with minor variations. The package for the portable channel to be used 
for calibration and setup is currently in the design stage. The portable package will contain all circuitry to be found in the channel module.

Three remote wall meter readout units are being fabricated; one for TCA and two for TCC. The first two units have been checked out and shipped to NRDS; one each for TCA and TCC. The third unit is still in fabrication and is awaiting parts. Inter connecting cables are to be fabricated in place for correct length.

LASL J-17 and WANL have requested that the remote bridge check capability of the new bridge signal conditioners be utilized. The capability has been diagrammed which uses the existing group inhibit circuitry along with new circuitry comparable to the existing remote calibration system. This proposal will be submitted to J-17 and WANL as soon as it is formalized.

\subsection{SYSTEM EVALUATION}

The Test Cell C Data System Evaluation report preparation is continuing.

Final data reduction efforts of the Computation and Data Reduction Section have been completed and commutator summary tables will be assembled during the coming week.

A new and updated outline for the overall report has been prepared and a rough draft of the first three sections of the report has been completed. Upon completion of the summary tables, test results will be tabulated and the Discussion and Conclusion Section of the report started. 
The revised estimated target date for completion of the rough draft is the 28th of February.

6.6 SWET

\subsubsection{Support Systems}

The following is the present status of the support system's SWET effort:

Communications:

Design complete. List of

parts to be ordered being

proposed. Fabrication

requests to be prepared shortly.

Photo:

Use of Wollensak Fastax Goose

Control Units being investigated.

Timing to be 1000 CPS hack marks

on film.

Camera mount for Wollensak Mirrotel

Fastax streak camera is being designed.

Television: Unless directed differently by LASL, the old FM transmission system will be used. Little or no fabrication will be required.

Core Motion: The use of "light wires" is being investigated as a method of blowing up the small core movement.

\subsubsection{Data Systems}

It has been decided that at least the following items will be fabricated for SWET. 
1) Excitation supply cross over unit and its control

2) Data Go-No-Go chassis

3) Time Code Generator - as yet undefined

4) FM/ FM Long Lines Termination Chassis

5) Data Calibration unit

6) Signal conditioning equipment for determining "zero time."

The following two items will probably be fabricated:

1) Dynamics amplifier output filter chassis.

2) Data recorder control chassis.

The data trailer is to be shipped from Los Alamos

to EG\&G, Las Vegas for refit and equipment installation.

EG\&G will order the required cables for SWET. It is hoped that the order can be placed by February 7, 1964. J-17 will determine the cable needs of the various groups and will pass this information to EG\&G.

The Data Go-No-Go chain is to be "bllocked out" for presentation to R. Brenton by February 17, 1964.

\subsubsection{Neutronics}

The sensitivity of the Reuter-Stockes fission chamber was determined at Triga to be approximately $1.7 \times 10^{-17}$ amperes per $\mathrm{nv}$. The gamma sensitivity is approximately $1 \times 10^{-14}$ amperes per $\mathbf{R}$ per hour.

The SWET log amplifier and several cable combinations were tested in the mixed fission spectrum of Triga. The data is being analyzed and a report written.

The studies to date indicate that standard FM recording of the in-core log data will provide sufficient accuracy. Reduction by repeating the signal about 20 times into the $A-$ to- $D$ converter should meet requirements for reconstructing the data. Further study into specific techniques is expected to lead to experimental verification of the overall recording and reduction scheme within a few weeks. 


\section{7 TEST CELL C OPERATIONS SUPPORT}

\subsubsection{Data Systems}

Approximately twelve Video Instrument amplifiers were repaired and modified to accept the variable gain card. The units have been sent to NRDS. The remaining amplifiers will be sent to the site as they are completed.

\subsubsection{Neutronics Systems}

Preparation of the system set-up procedures is continuing, as is control tank checkout. A leak occured in one of the water tank detectors and is in the process of being corrected.

\subsubsection{Control Systems}

The reactor power system checkout is progressing. Zero start-up circuitry was designed and installed. This circuit will permit "closed loop" start-up from the source power level. 


\section{SECTION 7 \\ ENGINEERING - PHOEBUS}

There has been no pertinent activity to report. 
SECTION 8

NETWORK ANALYSIS

\section{1 ROVER INVENTORY}

TCA inventory has been updated periodically and new

lists generated. TCC information is now 70 percent complete on cards.

Sort programs for master tapes and manipulated data for System, Property No., and Location Sorts are 85 percent complete.

Printouts of our activities will be forwarded to Boston in the very near future for their review. 


\section{APPENDI $\mathrm{X} A$}

\section{TEST CELL A AREA}

CHANNEL ENGINEERING AND WI RING RECORDS

\section{Channel Engineering}

Activity at Test Cell A included installation of the NRX-A1 cart channels, and approximately 70 percent of the $\mathrm{LN}_{2}$ Dewar channels.

Test Cell A is 95 percent complete.

The following table reflects the status of Test Cell A systems relative to Channel Engineering.

CHANNEL ENGINEERING

\begin{tabular}{ccrrrr}
\hline System & $\begin{array}{c}\text { Completed in } \\
\text { January }\end{array}$ & $\begin{array}{c}\text { Total in } \\
\text { System }\end{array}$ & $\begin{array}{c}\text { Percent } \\
\text { Completed }\end{array}$ & $\begin{array}{r}\text { Incomplete } \\
\text { Inevised }\end{array}$ \\
\hline A & 559 & 506 & 96 & 18 & 56 \\
B & - & 5 & 40 & 3 & - \\
C & 21 & 33 & 69 & 10 & - \\
D & - & 15 & 100 & - & - \\
E & - & 9 & 100 & - & - \\
F & - & 24 & 100 & - & - \\
G & - & 69 & 100 & 1 & 5 \\
I & - & 412 & 99 & - & - \\
J & - & 16 & 100 & 2 & - \\
K & 16 & 47 & 95 & 33 & - \\
L & 6 & 245 & 86 & 2 & - \\
M & - & 34 & 94 & 2 & - \\
N & - & 78 & 92 & - & - \\
P & - & 79 & 100 & 2 & 9 \\
Q & 2 & 124 & 98 & 16 & - \\
R & 17 & 176 & 90 & 9 & - \\
S & - & 116 & 92 & 1 & - \\
T & - & 28 & 96 & - & - \\
U & - & 26 & 100 & - & - \\
V & - & 502 & 100 & 7 & \\
Z & - & 24 & 70 & & - \\
\hline
\end{tabular}




\section{Wiring Records}

The following table reflects the status of Test Cell A systems relative to Wiring Records.

\section{WIRING RECORDS}

\begin{tabular}{|c|c|c|c|c|c|c|c|}
\hline Jystem & $\begin{array}{c}\text { No. Channels } \\
\text { in System }\end{array}$ & $\begin{array}{c}\text { Completed in } \\
\text { January }\end{array}$ & $\begin{array}{r}\text { Net Total } \\
\text { Completed } \\
\end{array}$ & $\begin{array}{l}\text { Percent } \\
\text { Completed } \\
\end{array}$ & $\begin{array}{r}\text { Incomplete } \\
\text { Channels } \\
\end{array}$ & $\begin{array}{l}\text { Rev- } \\
\text { ised }\end{array}$ & $\begin{array}{l}\text { Can- } \\
\text { celled }\end{array}$ \\
\hline A & 506 & 481 & 487 & 96 & 19 & 63 & 149 \\
\hline B & 5 & 0 & 2 & 40 & 3 & - & - \\
\hline C & 33 & 9 & 10 & 33 & 23 & - & - \\
\hline D & 15 & 0 & 15 & 100 & 0 & 15 & $\ldots$ \\
\hline $\mathbf{E}$ & 9 & 0 & 9 & 100 & 0 & - & 10 \\
\hline $\mathrm{F}$ & 24 & 0 & 24 & 100 & 0 & 1 & - \\
\hline G & 69 & 0 & 69 & 100 & 0 & 25 & 1 \\
\hline I & 412 & 0 & 410 & 99 & 2 & 15 & 1 \\
\hline $\mathrm{J}$ & 16 & 0 & 16 & 100 & 0 & 2 & - \\
\hline $\mathrm{K}$ & 47 & 11 & 40 & 94 & 7 & 20 & - \\
\hline $\mathrm{L}$ & 245 & 5 & 212 & 86 & 33 & 69 & $=$ \\
\hline $\mathbf{M}$ & 34 & 0 & 32 & 94 & 2 & 2 & - \\
\hline $\mathbf{N}$ & 78 & 0 & 72 & 93 & 6 & - & - \\
\hline $\mathbf{P}$ & 79 & 0 & 79 & 100 & 0 & - & 10 \\
\hline $\mathbf{Q}$ & 124 & 0 & 122 & 98 & 2 & 46 & - \\
\hline $\mathbf{R}$ & 176 & 25 & 160 & 90 & 16 & 20 & - \\
\hline$S$ & 116 & 0 & 104 & 90 & 12 & 3 & 7 \\
\hline $\mathrm{T}$ & 28 & 0 & 27 & 97 & 1 & 2 & 1 \\
\hline $\mathrm{U}$ & 26 & 0 & 26 & 100 & 0 & 1 & - \\
\hline $\mathrm{V}$ & 502 & 0 & 484 & 96 & 18 & - & - \\
\hline Z & 24 & 0 & 17 & 70 & 7 & 11 & - \\
\hline
\end{tabular}


TEST CELL C AREA

CHANNEL ENGINEERING AND WIRING RECORDS

\section{Channel Engineering}

The major work at Test Cell $\mathbf{C}$ consisted of channel revisions for the Kiwi-B4D/CF tests, and cancellation of the channels installed for the Acoustios tests.

Test Cell $\mathrm{C}$ is 9.8 peraent complete

The following table reflects the status of Test Cell C systems relative to Channel Engineering.

CHANNEL ENGINEERING

\begin{tabular}{ccrrrr}
\hline System & $\begin{array}{c}\text { Complet ed in } \\
\text { January }\end{array}$ & $\begin{array}{r}\text { Total in } \\
\text { System }\end{array}$ & $\begin{array}{c}\text { Percent } \\
\text { Completed }\end{array}$ & Incomplete & Revised \\
\hline A & 1 & 249 & 100 & - & 45 \\
B & - & 6 & 83 & 1 & 2 \\
C & - & 148 & 100 & - & - \\
E & 2 & 91 & 95 & 2 & - \\
F & - & 21 & 90 & - & - \\
G & - & 34 & 100 & 1 & - \\
H & - & 74 & 98 & - & 1 \\
I & - & 280 & 100 & - & - \\
J & - & 19 & 100 & - & 1 \\
K & - & 30 & 100 & - & 1 \\
L & 2 & 195 & 100 & 7 & - \\
M & - & 33 & 78 & - & - \\
N & - & 59 & 100 & 9 & - \\
P & - & 63 & 85 & - & 2 \\
Q & 5 & 183 & 100 & - & - \\
R & - & 126 & 100 & 16 & 1 \\
S & - & 161 & 90 & - & - \\
T & 1 & 18 & 100 & 1 & 1 \\
U & - & 27 & 96 & - & - \\
V & - & 384 & 100 & - & 1 \\
X & - & 23 & 100 & - & - \\
Y & - & 69 & 100 & - & \\
Z & - & 20 & 100 & & \\
\hline
\end{tabular}




\section{Wiring Records}

The following table reflects the status of Test Cell $\mathrm{C}$ systems relative to Wiring Records.

\section{WIRING RECORDS}

\begin{tabular}{cccccccc}
\hline System & $\begin{array}{c}\text { No. Channels } \\
\text { in System }\end{array}$ & $\begin{array}{c}\text { Completed in } \\
\text { January }\end{array}$ & $\begin{array}{c}\text { Net Total } \\
\text { Completed }\end{array}$ & $\begin{array}{c}\text { Percent } \\
\text { Completed }\end{array}$ & $\begin{array}{c}\text { Incomplete } \\
\text { Channels }\end{array}$ & $\begin{array}{c}\text { Rev- } \\
\text { ised }\end{array}$ & $\begin{array}{c}\text { Can- } \\
\text { celled }\end{array}$ \\
\hline A & 249 & 7 & 249 & 100 & 0 & 43 & 6 \\
B & 6 & 0 & 5 & 83 & 1 & 3 & 2 \\
C & 148 & 0 & 148 & 100 & 0 & - & - \\
E & 91 & 22 & 87 & 96 & 4 & - & - \\
F & 21 & 0 & 19 & 90 & 2 & - & - \\
G & 34 & 0 & 34 & 100 & 0 & 9 & 1 \\
H & 74 & 0 & 73 & 98 & 1 & - & - \\
I & 280 & 0 & 280 & 100 & 0 & 4 & - \\
J & 19 & 0 & 19 & 100 & 0 & - & - \\
K & 30 & 0 & 30 & 100 & 0 & 1 & - \\
L & 195 & 0 & 195 & 100 & 0 & 1 & 7 \\
M & 33 & 0 & 26 & 80 & 7 & - & - \\
N & 59 & 0 & 59 & 100 & 0 & - & - \\
P & 63 & 0 & 52 & 82 & 11 & - & 16 \\
Q & 183 & 0 & 183 & 100 & 0 & 2 & 5 \\
R & 126 & 0 & 126 & 100 & 0 & - & - \\
S & 161 & 2 & 145 & 90 & 16 & 6 & 4 \\
T & 18 & 1 & 18 & 100 & 0 & - & - \\
U & 27 & 0 & 26 & 99 & 1 & 1 & - \\
V & 384 & 0 & 384 & 100 & 0 & - & - \\
X & 23 & 0 & 23 & 100 & 0 & 1 & - \\
Y & 69 & 0 & 69 & 100 & 0 & - & - \\
Z & 20 & 0 & 20 & 100 & 0 & - & - \\
\hline
\end{tabular}




\section{APPENDIX B}

\section{TRIPS AND CONF ERENCES}

B. P. Warner, General Atomics, 7-8 January (SWET)

J. J. Smith, General Atomics, 6-8 January (SWET)

R. Winn, R. Lawson, D. Robinson, and L. Gilmore, General Atomics, 6-11 January (SWET)

*C. Beaudette, P. Maleckos, M. Schiff to LASL, EG\&GLas Vegas and J-7 NRDS

* Boston Personnel 


\section{APPENDIX C}

\section{REPORTS ISSUED DURING JANUARY}

Report No. L-637

Rover Progress Report

for December 1963. 


\section{APPENDIX D \\ OVERTIME REPORT}

The following is a tabulation by name and by week of overtime beyond 40 hours worked during this reporting period.

\begin{tabular}{|c|c|c|c|c|c|}
\hline & Hou & Personnel & & & \\
\hline & 5 Jan. & $12 \mathrm{Jan}$. & $19 \mathrm{Jan}$. & 26 Jan. & Total \\
\hline Allison, L. A. & & 4 & & 3 & 7 \\
\hline Amadon, C. R. & 16 & 2 & & 1.5 & 19.5 \\
\hline Ard, J. & & & & 2 & 2 \\
\hline Arumbula, L. R. & & 2 & & & 2 \\
\hline Baldwin, B.A. & & & & 8 & 8 \\
\hline Barksdale, J.E. & & & 8 & 8 & 16 \\
\hline Berger, R.L. & & 6 & 15 & 14 & 35 \\
\hline Bickerstaff, R.J. & & 8 & & 12 & 20 \\
\hline Bond, R. D. & & & & 8 & 8 \\
\hline Brewer, O.G. & & & 8 & 8 & 16 \\
\hline Bryant, B. N. & & 7 & 11.5 & 4 & 22.5 \\
\hline Burgon, L. M. & & & & 8 & 8 \\
\hline Chamberlain, D.C. & & 2 & & & 2 \\
\hline Clemmons, R. N. & 8 & 2 & & 3.5 & 13.5 \\
\hline Criddle, R. D. & & & 8 & 8 & 16 \\
\hline Crites, G. P. & & & 8 & 6.5 & 14.5 \\
\hline Dungan, F. R. & & 2 & & 1.5 & 3.5 \\
\hline Eck, F. & 8 & 2.5 & & & 10.5 \\
\hline Elliot, G. & 8 & & & & 8 \\
\hline Elmer, W. F. & & 4 & & 5 & 9 \\
\hline Fisher, E. H. & & 9 & & & 9 \\
\hline Garten, J. L. & & & 11.5 & 8 & 19.5 \\
\hline Gilgan, R.J. & & & 8 & 8 & 16 \\
\hline Goplin, R. & & 2 & & & 2 \\
\hline Gremore, $\mathbf{R}$. & & & 8 & 8 & 16 \\
\hline Herry, R. E. & & 4 & & & 4 \\
\hline Hill, G. C. & & & 8 & 6.5 & 14.5 \\
\hline Hillman, D. $R$. & & & 8 & 8 & 16 \\
\hline Hungate, K. L. & & & 11.5 & 2 & 13.5 \\
\hline Hurick, L. & & 2 & & & 2 \\
\hline Jackson, D.C. & & 2 & & & 2 \\
\hline Johnston, R. & & & & 8 & 8 \\
\hline Kelly, W. T. & & 6 & & 8 & 14 \\
\hline Lancaster, D. L. & & 9.5 & & & 9.5 \\
\hline Leu, V.D. & & 2 & & & 2 \\
\hline Lloyd, C. P. & & 9.5 & & 8 & 17.5 \\
\hline Mackenzie, J. M. & 8 & & & & 8 \\
\hline
\end{tabular}




\begin{tabular}{|c|c|c|c|c|c|}
\hline & 5 Jan. & 12 Jan. & 19 Jan. & 26 Jan. & Total \\
\hline Marsh, J. & 8 & 8 & & & 16 \\
\hline Mc Entire, J. B. & & & & 8 & 8 \\
\hline McKague, C. E. & & 4 & & 3.5 & 7.5 \\
\hline Moeller, A.E. & & 4 & & 8 & 8 \\
\hline Noyes, R. P. & & & & 8 & 8 \\
\hline Nyden, R. W. & & & 8 & 8 & 16 \\
\hline Patterson, J.E. & & & 8 & 8 & 16 \\
\hline Porter, G. O. & 8 & 2.5 & & 3.5 & 14 \\
\hline Pruitt, C.S. & & 6 & & 8 & 14 \\
\hline Quinn, V. & & 6 & & 8 & 14 \\
\hline Ross, S. P. & & 8 & & & 8 \\
\hline Smith, J.E. & & & 8 & 8 & 16 \\
\hline Snively, T. L. & & 4 & & 5 & 9 \\
\hline Spendlove, J. & & & & 8 & 8 \\
\hline Szpotowski, F. & & 4 & & & 4 \\
\hline Terry, D. & & 7 & & 6 & 13 \\
\hline Thompson, J. & & & 8 & & 8 \\
\hline Thompson, P. & & & 3.5 & & 3.5 \\
\hline Trupp, S. G. & & & 8 & 8 & 16 \\
\hline Wadsworth, G.P. & & & & 7 & 7 \\
\hline Welsh, J.R. & & 2 & & 8 & 10 \\
\hline Woodruff, K. E. & & & & 5 & 5 \\
\hline
\end{tabular}




\section{APPENDIX E \\ PERSONNEL LEVEL REPORT \\ JANUARY \\ IC $3001-1$}

1. Test Cell $\mathbf{C}$ Installation and Operations

*Hours

Men

3. Data Reduction

4. Engineering Support, Test Cell C

5. Engineering Support, Phoebus

6. PERT

\begin{tabular}{|c|c|}
\hline 40. & 74 \\
\hline 40 & 9 \\
\hline 40 & 16 \\
\hline 40 & 2 \\
\hline 40 & 1 \\
\hline
\end{tabular}

IC $3001-2$

1. Test Cell A Installation and Operations

2. Engineering Support, Test Cell A

$\frac{41}{40}-\frac{64}{10}$

Total

* Overtime as outlined, represents all overtime charges incurred regardless of whether it was incurred by an operational job number or a capital equipment job number. Average hour-per-week reflects only those hours which are incurred by operational job numbers while those incurred by capital equipment job numbers have been deleted. 
K. P. Boyer, J-Division, LASL

R. W. Spence, N-Division, LASL

J. Hens hall, J-17, NTS (3)

R. Brenton, j-17, NTS

G. Fenstermacher, LASL

A. M. Koonce, J-8, LASL

J. E. Perry, N-4, LASL

L. G. Hawkins, BUD, LASL

V. Tyler, EG\&G Boston (6)

RTED (1)

LASL Mall \& Records

D. W. King, ALO

A. A. Fleischer, Santa Barbara

Rover Reports File, Las Vegas

Rover Reports File, Boston

EG\&G RTOD Report File, NTS-2 

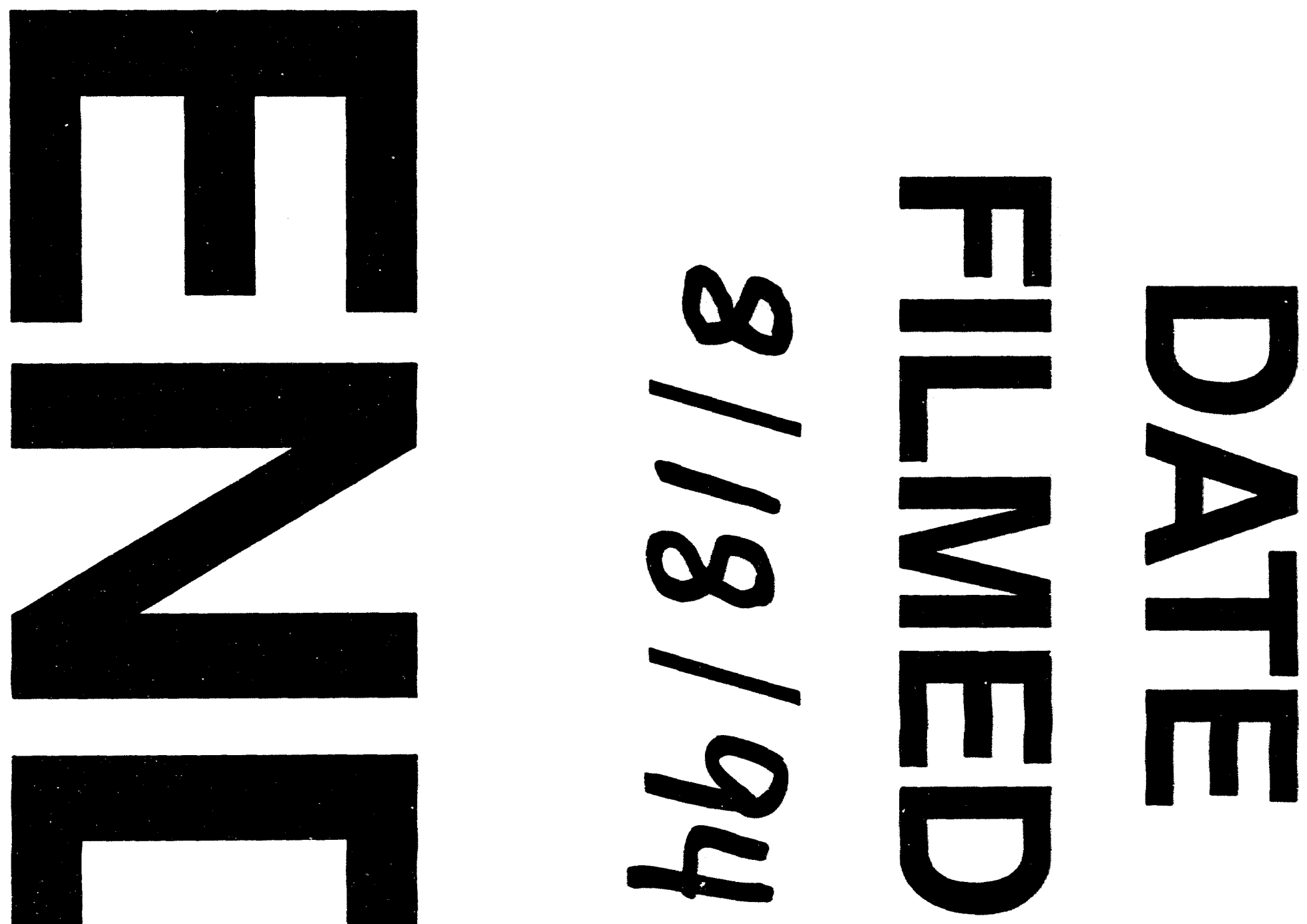


$$
\text { - }
$$

